\title{
Contribuições do Papa Francisco para o diálogo inter-religioso: um tópico a aprofundar a partir dos discursos do Papa Francisco em suas viagens internacionais - Parte II
}

\author{
Orientadora: Profa. Maria Teresa de Freitas Cardoso \\ Pesquisador: José Ronaldo Venâncio dos Santos \\ Fonte: $\mathrm{CNPq}$
}

\section{Introdução}

Nesta segunda fase da pesquisa, prosseguiremos com o assunto sobre o diálogo inter-religioso, a partir do pontificado do Papa Francisco, em especial em seus discursos nas suas viagens internacionais. Buscaremos elencar pensamentos e vertentes que exprima por meio deste diálogo que poderemos chegar a uma cultura de paz. Ainda tomamos sua exortação apostólica Evangelii Gaudium como um dos documentos mais importantes do ponto de partida desta temática.

Este estudo buscará mostrar que todos são chamados a esse caminho de diálogo inter-religioso para se atingir uma cultura de paz, que por ele todos são irmãos e irmãs. Assim, recorda o Papa Francisco que a responsabilidade do diálogo inter-religioso aponta para uma nova forma de convivência mundial, para o que ele chama de "civilização da paz e do encontro". Dessa maneira veremos no decorrer desta pesquisa, que o sumo pontífice em suas viagens internacionais aponta que juntos, declaramos a sacralidade de cada vida humana contra qualquer forma de violência física, social, educativa ou psicológica.

Contudo, a fé que não nasce de um coração sincero e de um amor autêntico a Deus Misericordioso é uma forma de adesão convencional ou social que não liberta o homem, mas esmaga-o. Portanto, quanto mais se cresce na fé em Deus, com tamanha intensidade se cresce no amor ao próximo. Por isso que 
o Santo Padre irá propor o diálogo inter-religioso como traço importante de evangelização para a Igreja em nosso tempo e para uma cultura de paz entre os povos.

\section{Objetivos}

Esse trabalho tem por objetivo averiguar os discursos do Santo Padre em suas viagens, que evidenciem que o Diálogo Inter-religioso pode e deve ser o meio mais eficaz para cultivar uma cultura de paz, bem como identificar as principais contribuições do Papa Francisco para os temas de Diálogo interreligioso e de solidariedade, que cooperem para as questões sistemáticopastorais sobre a Igreja e os diálogos, segundo a vocação e missão da Igreja. 